\title{
A contribution to late Middle Paleolithic chronology of the Levant: New luminescence ages for the Atlit Railway Bridge site, Coastal Plain, Israel
}

Porat, N. ; Jain, Mayank; Ronen, A.; Horwitz, L.K.

Published in:

Quaternary International

Link to article, DOI:

10.1016/j.quaint.2017.06.017

Publication date:

2018

Document Version

Peer reviewed version

Link back to DTU Orbit

Citation (APA):

Porat, N., Jain, M., Ronen, A., \& Horwitz, L. K. (2018). A contribution to late Middle Paleolithic chronology of the Levant: New luminescence ages for the Atlit Railway Bridge site, Coastal Plain, Israel. Quaternary International, 464(Part A), 32-42. https://doi.org/10.1016/j.quaint.2017.06.017

\section{General rights}

Copyright and moral rights for the publications made accessible in the public portal are retained by the authors and/or other copyright owners and it is a condition of accessing publications that users recognise and abide by the legal requirements associated with these rights.

- Users may download and print one copy of any publication from the public portal for the purpose of private study or research.

- You may not further distribute the material or use it for any profit-making activity or commercial gain

- You may freely distribute the URL identifying the publication in the public portal 
1 A contribution to late Middle Paleolithic chronology of the Levant: New

2 luminescence ages for the Atlit Railway Bridge site, Coastal Plain, Israel

3 N. Porat ${ }^{(1)}$, M. Jain ${ }^{(2)}$, A. Ronen ${ }^{(3)}$, L.K. Horwitz(4).

4

5 (1) The Geological Survey of Israel, 30 Malkhe Israel St., Jerusalem 95501, Israel

6 (2) Radiation Research Division, Risø National Laboratory, Technical University of 7 Denmark (Risø DTU), DK-4000 Roskilde, Denmark

8 (3) Zinman Institute of Archaeology, University of Haifa, Haifa 31905, Israel

9 (4) Natural History Collections, Faculty of Life Sciences, The Hebrew University, Jerusalem 91904, Israel 


\section{Abstract}

12 The Atlit Railway Bridge (ARB) prehistoric site is located on the northern coastal plain of Israel, within natural caves which formed within calcareous aeolianites (kurkar), perhaps during a high sea-stand. Flint artifacts and faunal remains were found embedded in the kurkar infill of two caves, and the artifacts belong to the Levantine later Mousterian tradition. The aeolianites in which the caves had developed were previously constrained by IRSL $_{50}$ dating of feldspars to be older than the last interglacial highest sea-stand (Frechen M. et al. 2004; Chronology of Pleistocene sedimentary cycles in the Carmel Coastal Plain of Israel. Quaternary International 121, 1-52), providing a maximum age for the artifacts.

21 Samples for luminescence dating were collected from the infill of the two caves (II and III), from the same deposits as the archaeological finds. Both quartz and alkali feldspars (KF) were extracted and measured using four different luminescence signals: optically

24 stimulated luminescence (blue OSL) and violet stimulated luminescence (VSL) on 25 quartz; and the infrared stimulated luminescence (IRSL) post-IR-IR 290 signal and the $\mathrm{IR}_{50}$ signal corrected for anomalous fading on KF. The ages obtained from analyses of the different minerals and signals mostly agree within errors. The new luminescence ages date the sediment infill in Caves III and II to $\sim 90 \mathrm{ka}$ and $\sim 70 \mathrm{ka}$, respectively, indicating that hominin occupation of this locality is coeval with the nearby Skhul Cave and Layer B in Tabun Cave.

\section{Key Words}

Blue OSL, VSL, IRSL, MIS 5, beachrock, eastern Mediterranean coast, Mousterian 


\section{Introduction}

The southern Levant is a critical region for examining hominin biological and cultural evolution during the Middle Paleolithic (MP), particularly given the presence of both Neanderthals and early anatomically modern humans in the region (McCown and Keith, 1939; Rak, 1998; Shea, 2010; Weinstein-Evron, 2015; Langdon, 2016). Moreover, lithic typologies attest to extensive inter-site variability during this period, but the factors responsible - different hominin abilities, socio-cultural choice and behaviours, climatic and local ecological factors, or chronology - are unclear (e.g. Jelinek, 1981; Bar-Yosef and Meignen, 1992; Goren-Inbar and Belfer-Cohen, 1998; Hovers, 2009; Belfer-Cohen and Hovers, 2010; Kadowaki, 2013). Finally, the timing and nature of the transition between the late MP and the Upper Paleolithic is of special interest, especially given the debate over cultural continuity and apparent association of this period with the dispersal of anatomically modern humans Out of Africa (Bar Yosef, 2002; Shea, 2008; BelferCohen and Goring-Morris, 2009; Hershkovitz et al. 2015). Consequently, dating MP sites is a critical issue.

Initially, radiocarbon was the principal source of chronometric data for the MP (e.g. Weinstein, 1984; Henry, 1992).Advances in this field of dating - including introduction of accelerator mass spectrometry, improved pretreatment chemistry of samples as well as statistical tools - still renders radiocarbon an essential tool for dating terminal MP sites (e.g. Bronk Ramsey et al., 2004; Bronk Ramsey, 2009; Taylor and Bar-Yosef, 2016). However additional radiometric methods are needed to date deposits and sites from early and middle MP which are beyond the limit of radiocarbon (ca. 40-60,000 years BP, Taylor and Bar-Yosef, 2016:24). Methods commonly applied to MP occupations include electron spin resonance (ESR) for teeth (see review by Grün, 2006), and luminescence dating methods which include among other techniques thermoluminescence (TL) for burnt flints (e.g. Valladas et al., 2013) and optical stimulated luminesce (OSL) for quartz grains in sediments (see review by Roberts et al., 2015). They have extended the range of dating for the MP considerably and improved precision of dating through cross-checking of ages between different methods to create a more robust chronometric framework for this period in the southern Levant (e.g. Mercier et al., 2013). The luminescence methods have proved especially useful, given 
that many sites lack organic remains (bones, teeth, charcoal) and contain only burnt flint and sediment.

As new techniques are developed in luminescence dating, there is a need to test them in sites where they can be compared to well-established methods such as radiocarbon or OSL (Wintle, 2008). Some of the new methods, such as violet stimulated luminescence (VSL; Jain, 2009), aim at dating samples older than $200 \mathrm{ka}$, a time range usually not covered by OSL. The best test case for a comparative study of luminescence methods is a site which is younger than $200 \mathrm{ka}$, is rich in both quartz and feldspars, and has some age control. Atlit Railway Bridge (ARB) is such a site; its relative age has been established by previous luminescence dating to be younger than the last interglacial high sea-stand (MIS 5e; Frechen et al., 2004); according to the lithic assemblage it is of late Mousterian age (Ronen et al., 2008); and it is situated in the coastal plain sandy aeolianites and soil sequence rich in quartz and feldspars.

Here we present a comparison of several luminescence methods on samples from ARB, show how the ages compare with each other, and provide a robust age for the site. These ages are then placed within the context of late MP chronology for the southern Levant.

\section{Background to the Study Region}

Mount Carmel and the adjacent coastal plain of northern Israel (Fig. 1) are characterized by a Mediterranean climate with a mean annual temperature of $19^{\circ} \mathrm{C}$ and annual precipitation of ca. $600-800 \mathrm{~mm}$. Varied habitats are available in this region, ranging from typical Mediterranean forests or maquis on Mount Carmel to dunes, swamps and agricultural land on the coastal plain (Orni and Efrat, 1971). The region is of immense importance for prehistory, with well over 200 documented prehistoric sites spanning a range of periods and cultures in an area of ca. 30,000 ha (Olami, 1984; Ronen, 1977; Tsatskin and Ronen, 1999; Nadel et al., 2012; Weinstein-Evron, 2015). Of particular note are several caves and rock shelters clustered on the western side of Mount Carmel (Tabun, Jamal, Skhul, el Wad, Sefunim, Kebara and Misliya), as well as other sites in northern Israel (Qafzeh, Amud, Manot) that have yielded a rich and lengthy record of archaeological remains dating to the Lower Paleolithic (Late Acheulian and AcheuloYabrudian cultural entities, ca. 500-220 ka) and Middle Paleolithic (Mousterian cultural entities, ca. 245-45 to 47 ka) (Garrod and Bate, 1937; Ronen, 1984; Weinstein-Evron et 
al., 2003; Bar-Yosef and Meignen, 2007; Shea, 2013; Hershkovitz et al., 2015;

Weinstein-Evron 2015). The MP sites are unparalleled in that they contain remains of both early anatomically modern humans (Skhul I-IX, Tabun C2, Manot; Qafzeh) and Neanderthals (Kebara 1-2, Tabun C1, Tabun B, Geula, Amud), making the Carmel in particular, and northern Israel in general, a unique region for the study of human evolution (e.g. McCown and Keith, 1939; papers in Akazawa et al., 1998; papers in Bar-Yosef and Pilbeam, 2000; Shea, 2010; Langdon, 2016).

Mousterian sites on the adjacent Carmel narrow coastal plain are, in contrast, ephemeral and comprise scanty cultural and organic remains embedded in aeolian calcarenite or red soils, locally termed kurkar and hamra, respectively (e.g. Ronen, 1977; Ronen et al., 1999; Galili et al., 2007; Ronen and Chernikov, 2010; Galili et al, this volume). One such occurrence is the Atlit Railway Bridge (ARB) locality, situated ca. $5 \mathrm{~km}$ northwest of the caves of Tabun and Skhul (Fig. 1; Ronen et al., 2007).

The topography of the Israeli coast is made up of four to five longitudinal Pleistocene kurkar ridges that run parallel (north-south) to the coast. These ridges alternate with troughs filled with clays, sands and alluvial sediments (Issar, 1968; Almagor, 2002; Frechen et al., 2004; Sivan and Porat, 2004). The ARB find locality, whose dating is the focus of this paper, lies in the third ridge from the west, commonly known as the "Carmel coast" or "Highway" ridge (Eytam and Ben-Avraham, 1992; Ronen et al., 2008).

\section{Geological background}

The "Highway" kurkar ridge adjacent to Atlit is composed of the following units, which were dated by Frechen et al. (2004) by IRSL $_{50}$ (from bottom to top; Fig. 2):

Unit 1: a basal indurated aeolianite dated to $153 \pm 31 \mathrm{ka}$.

Unit 2: a reddish loam.

Unit 3: beachrock composed of complete and large fragments of shells in a coarse sand matrix, of variable thickness, occurring at elevations ranging between +4 and $+9 \mathrm{~m}$ asl. The presence of the fossil mollusk, Persitistrombus latus (formerly Strombus bubonius or S. latus), indicates a Last Interglacial age (MIS 5; Gignoux 1913). Using the elevation, the age of the unit can further be constrained to the peak of the last interglacial (MIS 5e; Galili et al., 2007). 
Unit 4: cemented aeolianite dated to $143 \pm 27 \mathrm{ka}$.

136 Unit 5: a sandy reddish loam dated to $76 \pm 7 \mathrm{ka}$.

137 Unit 6: the latest aeolianite on the ridge dated to $60 \pm 17 \mathrm{ka}$.

138 Unit 7: a largely eroded sandy reddish loam dated to $12 \pm 2 \mathrm{ka}$.

139 Three natural caves (I, II, III) were identified on the flanks of this kurkar ridge (Fig. 2;

140 Frechen et al., 2004; Ronen and Chernikov, 2010). The caves open to both the eastern

141 and western aspects of the ridge and Ronen et al. (2008) have suggested that they were

142 perhaps formed following marine abrasion during a high stand of the sea. The cave infill

143 comprises loosely cemented layer of finely crushed, tiny shell fragments disseminated

144 in a coarse sand matrix. The densest concentration of cultural remains, i.e. indicating the

145 most intensive hominin occupation, were found in the uppermost portion of the infill,

146 with scant remains in the lower fill. The layer bearing the cultural deposit was covered

147 by an unconsolidated fine, whiter sand ca. 5-20 cm thick, also containing rare fragments

148 of shell. This layer has been interpreted as representing a retreat of the coast line (Ronen

149 et al., 2008). The cultural deposit and overlying quartz sand layer in both caves were

150 capped by large blocks of roof collapse (Fig. 3a).

\section{Archaeological background}

153 In 2002, collections were made of archaeological remains that had eroded out of the

154 caves or were exposed in the cave fill (Ronen et al., 2008). The find location of all items

155 collected was noted and the stratigraphy of the infill documented (Fig. 3). The fill of

156 Cave I appears to be archaeologically sterile and cultural remains were found only in the

157 eastern entrances of Caves II and III. At this time, samples were collected from the

158 archaeological units of Cave II and III for luminescence dating.

160 Cave II: The cave entrance is $7.7 \mathrm{~m}$ wide and $5 \mathrm{~m}$ high. A narrow chimney $(0.5 \mathrm{~m}$

161 diameter), located adjacent to the south wall of the cave, leads to the base of the red loam

162 (Unit II) some $2.6 \mathrm{~m}$ up (Fig. 3b). The Unit III deposit is ca. $2 \mathrm{~m}$ thick and contains two

163 hearths ( $\mathrm{H} 1$ and $\mathrm{H} 2)$, lithic tools and fauna. The hearths were visible in the sections and

164 were characterized by dark, well constrained lenses. H1 was black, while the upper part of

$165 \mathrm{H} 2$ was black while the lower part was pinkish in color. H1 was $\sim 30 \mathrm{~cm}$ in length and 5

$166 \mathrm{~cm}$ thick and lay at the top of the cultural layer, while $\mathrm{H} 2$ was $\sim 50 \mathrm{~cm}$ in length and $8 \mathrm{~cm}$

167 thick, and lay at a lower elevation within this deposit (Fig. 5 in Ronen et al., 2008). Both

168 hearths were surrounded by lithic artifacts and flakes, with one burnt flake each, 
respectively. In the vicinity of $\mathrm{H} 1$ there was a poorly preserved long bone shaft fragment and a small fragment of ostrich eggshell, while isolated fragments of animal bone were found around $\mathrm{H} 2$. This unit is covered by a layer of unconsolidated fine white sand overlain by small aeolianite debris and large blocks of roof collapse.

Cave III: The cave entrance is $7.3 \mathrm{~m}$ wide and $1.7 \mathrm{~m}$ high (Fig. 3c). Several concentrations of relatively well preserved animal bones and a tooth were found intermingled with lithic artefacts. Seashells were found mainly close to the surface of the cultural deposit, while one shell and a flake were found in the middle of the infill. Unconsolidated white sand was deposited above the beachrock and the whole infill was sealed by huge blocks from the collapsed cave roof.

Lithic assemblage: A small lithic assemblage of ca. 20 items was recovered from the ARB caves, mostly derived from Cave II. The lithic assemblage was manufactured on high quality brown Mount Carmel flint. Both artefacts and flakes are fresh and were found horizontally aligned in the deposit. The use of Levallois technique clearly predominates with dihedral, faceted or 'chapeau-de-gendarme' flake butts. No cores were found and most artefacts were complete. Two retouched tools were found (a straight side-scraper, a backed knife; Fig. 5) as well as several lightly retouched/used pieces (e.g. Ronen 2008: Fig 7, items 4 and 7). When present, retouch was generally light (Ronen et al. 2008).

The artifacts show features comparable with those from both Layers B and C of nearby Tabun Cave (attributed to the Middle and Late Mousterian, respectively) and Skhul Layer B (Jelinek, 1982; Ronen et al., 2008; Shea, 2010, 2013; Culley et al., 2013). The ARB finds also resemble other late Mousterian lithic assemblages recovered in the red loam (Hamra) deposits along the Carmel coast (Issar and Kafri, 1969; Ronen, 1977, 1983; 1994; Tsatskin and Ronen, 1999; Galili et al., 2007; Ronen and Chernikov, 2010). The absence of abrasion on the ARB tools and their horizontal position in the deposit suggest that the artefacts are in primary position, with little or no disturbance.

Faunal assemblage: Fauna are not preserved in the red loam Mousterian find localities along the Israeli Mediterranean coast (Ronen and Chernikov, 2010). They are however, preserved at the ARB site, and in four other find spots within kurkar on the Carmel and Galilee coasts (Galili et al., 2007). 
204 The majority of faunal remains from ARB that could be identified to taxon were recovered from Cave III (Fig. 4; Table 1). The range of species identified resembles that found in other Mousterian sites in northern Israel, notably those in Mount Carmel (e.g. Garrard, 1982; Weinstein-Evron et al., 2003; Yeshurun et al., 2007; Speth, 2012; MarínArroyo, 2013): Persian fallow deer (Dama mesopotamica), mountain gazelle (Gazella gazella), aurochs (Bos primigenius), ostrich (Struthio camelus) and spur-thighed tortoise (Testudo graeca).

Four species of Mediterranean marine shells were also recovered - Donax trunculus,

213 Cerastoderma traucum, Acanthocardia tuberculata and Glycymeris nummaria

214 (previously G. insubrica) (Ronen et al., 2008). A well rounded perforation in the umbo 215 of one of the G. nummaria valves (Fig. 4d) may have been intentionally man-made. It 216 has not been possible to establish whether the shells were introduced into the cave by 217 hominins or a natural agent, especially since they were found close to the top of the 218 cultural fill, albeit together with lithic artefacts and fauna. Glycymeris shells have been 219 reported from MP layers in the inland sites of Skhul, Qafzeh and Sefunim (Bar-Yosef 220 Mayer, 2005; Bar-Yosef Mayer et al., 2009), indicating that this marine mollusk was 221 exploited by local hominins (in all instances, early Homo sapiens). At Skhul, aside from 222 G. nummaria, other species of Mediterranean marine shells were also found; Cardium 223 sp., Nassarius gibbosulus and Pecten jacobaeus. At these sites, the umbos' of the shells 224 had natural perforations, but there was evidence of ochre staining and use-wear marks 225 leading to the conclusion that they were used as ornaments (Bar-Yosef Mayer, 2005, 226 Bar-Yosef Mayer et al., 2009). Moreover, it has been suggested that since the $G$. 227 nummaria shells found in Sefunim Cave in Mount Carmel were abraded, that they were 228 old shells intentionally collected for ornaments rather than for consumption (Bar-Yosef 229 Mayer et al., 2009).

231 The small size of the recovered archaeological assemblage and the fact that it was collected rather than excavated, necessitates exercising some caution when interpreting these remains. However, it is possible that the ARB site and others like it functioned as sea-shore camps for collection of marine shells and other resources which were then taken or exchanged inland. 


\section{Luminescence dating}

239 Samples for dating were collected from Cave II and Cave III infills, from deposits 240 associated with bones and flint artifacts (Fig. 3). As the sediment is highly indurated, 241 the samples were taken as blocks and were later cleaned and processed in a lab with appropriate low level orange lighting. Field and laboratory data are given in Table 2.

244 Quartz and feldspars were purified by gentle crushing of the blocks, sieving to the selected grain sizes, dissolving carbonates by $8 \% \mathrm{HCl}$, followed by a 2 -step density separation at $2.62 \mathrm{gr} / \mathrm{cm}^{3}$ and $2.58 \mathrm{gr} / \mathrm{cm}^{3}$ using sodium-polytungstate. The quartz-rich fraction (heavier than $2.62 \mathrm{gr} / \mathrm{cm}^{3}$ ) was further cleaned using magnetic separation (1.4 A on the Frantz magnetic separator) and etching with 40\% HF (for $40 \mathrm{~min}$ ), followed by soaking in $16 \% \mathrm{HCl}$ to dissolve any fluorides which may have precipitated. The concentrated potassium feldspar (KF) grains (lighter than $2.58 \mathrm{gr} / \mathrm{cm}^{3}$ ) were not etched.

Dose rates: Alpha, beta and gamma dose rates (Table 2) were calculated from the concentrations of the radioactive elements in the sediment measured by atomic absorption spectroscopy $(\mathrm{K})$ or inductively coupled plasma mass-spectrometry (U and Th), with relative errors of $3 \%, 5 \%$ and $10 \%$, respectively, and attenuation factors as in Nambi and Aitken (1986). Although the measured K-contents of the KF range from 10.5 to $11.1 \%$, the internal beta dose rate for KF was calculated using a K-content of $12.0 \pm 0.5 \%$. This value was selected as grains with the brightest infra-red stimulated luminescence (IRSL) signals have such K-contents (Smedley et al., 2012), and in multigrain measurements such grains will dominate the signal. This value is somewhat lower than that suggested by Huntley and Beril (1997), $12.5 \pm 0.5 \%$. The a-value was estimated at $0.15 \pm 0.05$, an average of the values given for KF by Balescu et al. (2007) and Rendel et al. (1993). Cosmic dose rate was evaluated from burial depth of $8 \pm 1 \mathrm{~m}$, at $85 \pm 8$ $\mu \mathrm{Gy} / \mathrm{a}$ (Prescott and Hutton, 1994). Moisture contents were estimated at $10 \pm 3 \%$.

The measured signals: Four different luminescence signals were used to determine the equivalent dose (De) values, and five De values were obtained for each sample to be used in the age calculations. Measurements were carried out using Risø TL/OSL readers 
equipped with calibrated ${ }^{90} \mathrm{Sr}$ beta sources either at the Geological Survey of Israel or at the DTU Nutech, Denmark. Measurement protocols are listed in Table 3.

Quartz optically stimulated luminescence (OSL) De was measured on 2-mm aliquots using blue LED stimulation with detection through $7.5 \mathrm{~mm} \mathrm{U}-340$ filters. Both the single aliquot regenerative dose (SAR; Table 3a; Murray and Wintle, 2000) and the single aliquot regenerated and added dose (SARA; Mejdahl and Bøtter-Jensen, 1994; Murray et al., 1995) protocols were used. The latter is used to check for any sensitivity change which may have occurred in the first measurement cycle and is not corrected for by the first test dose normalization (Table 3a). Twenty-four aliquots were used to construct the SARA plot, whereby the De is measured using the SAR protocol on several aliquots of the natural sample, as well as on aliquots of the natural sample that received a range of added laboratory doses. The measured De is plotted against the added doses and the intercept of the SARA curve with the added dose axis is the natural De (Fig. 6). A slope of unity indicates that no sensitivity change took place in the first measurement cycle

Quartz violet stimulated luminescence (VSL) was measured on 8-mm aliquots using the SAR protocol in Table $3 b$ (modified from Jain 2009). Stimulation was with a solid state violet (405 nm) laser diode and a setup as in Jain (2009). Detection was through a $7.5 \mathrm{~mm}$ U340 filter combined with a Semrock Brighline $340 \mathrm{~nm}$ interference filter (Ankjaegaard et al., 2013).

Alkali feldspar infrared stimulated luminescence (IRSL) was measured on 2-mm aliquots in stainless steel cups using the SAR protocol in Table 3c (Thiel et al. 2011) which measures both the $\mathrm{IR}_{50}$ and the pIRIR 290 signals. Stimulation was by IR diodes $(880 \mathrm{~nm})$ and detection was through a Schott BG-39 and a Corning 7-59 filter pack, used to cut off the IR stimulation and relatively enhance the violet emission from the KF. Anomalous fading was measured for the three samples (six aliquots each) for up to 44 hours following Buylaert et al. (2008) and the $\mathrm{IR}_{50}$ ages were corrected for the measured fading rates as in Huntley and Lamothe (2001) using the R luminescence package (2015). 
For all samples and signals the average and errors were calculated using the central age model (CAM; Galbraith and Roberts, 2012). For SARA the error on the De was calculated from the goodness of fit.

\section{Luminescence Results}

Typical luminescence signals, dose response curves and De distribution (as probability density functions) are shown in Figure 7 for the OSL, pIRIR 290 and VSL signals. Figure 7 (panels c. f. and i.) and Table 2 show that the pIRIR 290 measurements are the least scattered, with overdispersion (OD) values of 6-8\%. For two of the three samples, quartz OSL is less scattered than quartz VSL.

OSL: overall the OSL signal is dominated by the fast component (Fig. 7a). Quality assurance parameters show that the SAR protocol can correct for sensitivity changes (recycling ratios within $10 \%$ of unity), there is no IR contamination (IR depletion ratio $>0.9)$, recuperation is negligible, and the natural OSL signal is far from saturation $\left(\mathrm{D}_{0}=\right.$ 45-55 Gy). SARA results are shown for sample ATL-1 (Fig. 6). The slope of the fitting line is 0.9 , suggesting that most sensitivity changes taking place in the first SAR cycle are corrected for adequately by the first test dose. The De calculated from the intercept, $54.6 \pm 6.6 \mathrm{~Gy}$, agrees very well with the conventional SAR De, 51.5 \pm 2.7 Gy (Table 2).

VSL: Fig. 7g shows a natural and regenerated VSL signals from sample ATL-4, and Figure $7 \mathrm{~h}$ presents a VSL dose response curve. The signal is overall weak and the data points on the DRC are often scattered; these were fitted with a double saturating exponential. Poor recycling ratios and high recuperation are prevalent. A comparison of the DRCs for quartz OSL and VSL (Figs. $7 \mathrm{~b}$ and $7 \mathrm{~h}$, respectively) shows that, while the curves cannot be compared directly due to different test doses, the DRCs from both signals have an onset of saturation at similarly low doses, and both signals have typical $\mathrm{D}_{0}$ of 45-65 Gy. A range of preheats in the VSL SAR protocol was tested to explore the possibility of reducing recuperation and increasing the $\mathrm{D}_{0}$ values. Increasing the preheat and cutheat temperatures to $310^{\circ} \mathrm{C}$ and $300^{\circ} \mathrm{C}$, respectively, increased the VSL $\mathrm{D}_{0}$ to about 100 Gy. It also decreased recuperation; however signal intensity decreased even further. 
336 IRSL: The ratio between the De values calculated from the $\mathrm{IR}_{50}$ and $\mathrm{pIRIR} 290$ signals is 337 0.5-0.6. Average measured fading rates were $2.9 \pm 0.5$ and $0.4 \pm 0.3 \%$ per decade for the

$338 \mathrm{IR}_{50}$ and pIRIR 290 signals, respectively, rendering fading corrections for the pIRIR 290 339 signal unnecessary. Even after correcting for fading, the $\mathrm{IR}_{50}$ ages are $20-25 \%$ lower 340 than the pIRIR 290 ages (Table 2). As the corrected $\mathrm{IR}_{50}$ ages are also younger than the 341 quartz VSL and OSL ages, it appears that the measured fading rates might not represent 342 fading in nature.

The ages: The ages obtained using the different minerals, luminescence signals and measurement protocols are overall comparable (Fig. 8), and in most cases are within errors of each other (notably, the VSL age for ATL-4 and the corrected $\mathrm{IR}_{50}$ age for ATL-2 are younger than the other results). Evidently, the hard-to-bleach signals such as the VSL and pIRIR 290 do not give higher ages, indicating that both quartz and feldspar grains were well bleached at the time of deposition. Samples ATL-1 and ATL-2 are from the same unit, and indeed their averaged ages are very similar, $87 \pm 9 \mathrm{ka}$ and $91 \pm 9$ ka, respectively. Although the De values for both minerals of sample ATL-4 are similar to the other two samples (Table 2), the dose rate is higher, resulting in a younger averaged age of $71 \pm 10 \mathrm{ka}$.

\section{Discussion}

The luminescence ages obtained here for the Atlit Railway Bridge sediments using four different signals show good correspondence. They also agree with the general chronostratigraphy presented by Frechen et al. (2004), but offer further refinement. We can better understand the sequence of events leading to cave formation and infill if we correct the IRSL ages in Frechen et al. (2004), measured at $50^{\circ} \mathrm{C}$, to fading rates measured from adjacent samples in this study.

The $\mathrm{IR}_{50}$ De values presented here, that were measured for the ARB samples using the

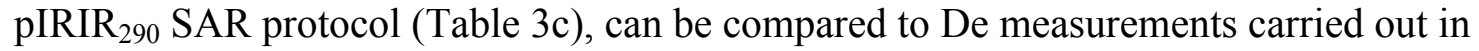

366 the past on the same samples using the $\mathrm{IR}_{50}$ signal and the single aliquot added dose

367 (SAAD) protocol (Duller, 1994), although preheats differed $-10 \mathrm{~s}$ at $290^{\circ} \mathrm{C}$ and $600 \mathrm{~s}$ at 

$220^{\circ} \mathrm{C}$, respectively. The SAAD De values (and hence the ages) are $10-13 \%$ lower than the SAR values, perhaps due to the lower preheat used for the SAAD. Nonetheless, as the SAAD IR 50 values are not far removed from the currently measured SAR IR 50 values, our measured fading rates can be used to correct IRSL ages measured in the past. The corrected ages should be taken only as a rough estimate of depositional age, as measurement protocols differed and the fading measurements carried out in this study were devised to correct for the SAR protocol (Auclair et al., 2003).

If we take this approach and correct the ages presented in Figure 2 using the averaged gvalue of $2.9 \pm 0.5$ measured for the ARB samples, then the fading-corrected ages are as follows:

Unit 1 kurkar that hosts the caves (Fig. 2): $195 \pm 42$ ka.

Unit 4 kurkar: $182 \pm 37$ ka.

Unit 5 paleosol: $96 \pm 11 \mathrm{ka}$.

Units 6 kurkar: $76 \pm 19$ ka.

Unit 7 soil: $15 \pm 3 \mathrm{ka}$.

The age of the beachrock filling the cave and underlying the archaeological beds is most likely $\sim 125 \mathrm{ka}$ (Galili et al., 2007). Thus, the lower kurkar units were deposited during MIS 7-6, the caves formed during the MIS 5e high sea-stand and soon after were partially filled with beachrock, and at $\sim 90 \mathrm{ka}$ and $\sim 70 \mathrm{ka}$ the caves were frequented by hominins, roughly at the same time when a soil formed at the top (Unit 5). The upper kurkar was deposited during MIS 4, at the same time interval that kurkar was deposited further to the south in the Sharon coast (Porat et al., 2004).

Taking all the ages obtained here, the best estimate of the time of deposition of the sediments embedding the lithic artifacts and fauna in Cave III is $\sim 90 \mathrm{ka}$, and that of Cave II is $\sim 70 \mathrm{ka}$. Possibly, the caves were used at different times as hominins were present in the region throughout these prehistoric periods.

The age range for Cave III, $\sim 80-100 \mathrm{ka}$, is comparable to the ages of the Mousterian Layer B in Tabun (104+30/-18 ka; Grün and Stringer, 2000) and is only somewhat younger than the Levantine-Mousterian found in Skhul (100-130 ka; Grun et al., 2005), located only $6 \mathrm{~km}$ to the south-east (Fig. 1). 
The range of Cave II, $71 \pm 10 \mathrm{ka}$, is comparable to that of the Mousterian site of Ein Qashish of 64 $\pm 4 \mathrm{ka}$, located $15 \mathrm{~km}$ inland as the crow flies (Greenbaum et al. 2014). Other late MP sites occur in the vicinity of Mount Carmel, but this is the only open air site to have been dated so far. While the direct aerial route between Atlit and Ein Qashish might be challenging - given that one would have to traverse Mount Carmel other more amenable routes to the coast, via either the Qishon Valley or Wadi Mileq, are only $\sim 35 \mathrm{~km}$ long. The relative proximity of these sites suggests that sorties to the coast by inhabitants located further inland such as Ein Qashish, may have taken place. This option is highlighted by the presence of Mediterranean seashells in the MP site of Qafzeh, located $45 \mathrm{~km}$ inland from the coast (Bar-Yosef Mayer et al., 2009).

Two MP hominin populations inhabited Mount Carmel close to the Atlit caves Neanderthals and modern humans (Garrod and Bate, 1937; McCown and Keith, 1939; Shea, 2010), over a period estimated by uranium series/ESR and TL dating to 165-100 ka (Mercier and Valladas, 2003; Grün et al., 2005). We can envisage a scenario whereby the hominins (Neanderthals and/or modern Homo) living in the Carmel caves and other inland sites visited the coast and occupied the smaller caves and other open air localities found within the coastal aeolianites (Ronen and Chernikov, 2010). Even with lowered sea level in MIS 5a of up to $-30 \mathrm{~m}$, the coastline was only 3-5 km away from Atlit. Given the ephemeral nature of occupation at ARB (shallow deposits, few finds, lack of evidence for on-site knapping), these late MP coastal occupations appear to represent short-lived camp sites, perhaps specifically focused on exploitation of marine and other coastal resources, rather than long term occupations such as known from the coeval Levantine caves (see discussion in Zaidner et al., 2016).

To place ARB within the larger chronological framework of the Middle Paleolithic of the southern Levant, we compared the ARB aged to those compiled for MP sites in the southern Levant by Shea $(2010 ; 2013)$. Shea (2013) divides the time frame of the MP into three main groupings: Phase 1, Early Mousterian that ranges from 240 to $130 \mathrm{ka}$, encompassing MIS 7 and 6; Phase 2, Middle Mousterian ranging from 130 to 75 which overlaps MIS 5; and Phase 3, Later Mousterian that starts at roughly $75 \mathrm{ka}$ and ends with the MP at $\sim 49 \mathrm{ka}$ (Rebollo et al., 2011), marking the transition to the Upper Paleolithic. From this division it is evident that the ARB ages fall in the transition between Phases 2 and 3. The lithic typology of the small assemblage of flakes and 
artefacts recovered from the ARB site show affinities to Tabun Layer C and B type industries, which according to Culley et al. (2013) demonstrate a high statistical affinity to each other. The age of ARB site thus suggests that hominins exploited Mediterranean coastal environments in the southern Levant, at least since $90 \mathrm{ka}$.

\section{Conclusions}

The two caves containing archaeological remains at Atlit Railway Bridge were dated by luminescence methods using four different signals, OSL, VSL, (fading corrected) $\mathrm{IR}_{50}$ and IRIR $_{290}$. The resulting ages show great consistency which increases our confidence in the dating methods and the resulting ages. These place the occupation time of Caves III and II at $\sim 90$ and $\sim 70 \mathrm{ka}$, respectively. After correcting the ages presented by Frechen et al. (2004) for anomalous fading, the kurkar in which the caves formed can be attributed to MIS 7 and 6, the cave infill within MIS 5 and the top of the kurkar section to MIS 4.

When placed within the cultural-chronological scheme published by Shea (2013), the occupation at ARB falls around the transition from middle to late MP in the region. This unique occurrence of lithics and fauna represents a coastal camp site occupied by hominins during the second half of the Mousterian, and is probably related to increased foraging mobility during MIS 5. The ARB site, though represented by a small collection of finds, expands our understanding of the repertoire of behaviors and sites occupied during the Levantine late MP.

\section{Acknowledgements:}

NP thanks DTU Nutech for facilitating her visit there in 2013 and the VSL measurements. We thank S. Zeffren for sample preparation and the Geochemistry laboratories at the GSI for chemical analyses of the sediments.

\section{References}

Akazawa, T., Aoki, K. and Bar-Yosef, O. (eds). 1998. Neandertals and Modern Humans in Western Asia, New York \& London: Plenum Press. 
Almagor, G. 2002. The Mediterranean Coast of Israel. Jerusalem: Geological Survey of Israel.

Ankjærgaard, C., Jain, M. and Wallinga, J. 2013. Towards dating quaternary sediments using the quartz violet stimulated luminescence (VSL) signal. Quaternary Geochronology 18, 99-109.

Auclair, M., Lamothe, M., Huot, S., 2003. Measurement of anomalous fading for feldspar IRSL using SAR. Radiation Measurements 37, 487-492.

Balescu, S., Ritz, J.-F., Lamothe, M., Auclair, M. and Todbileg, M. 2007. Luminescence dating of a gigantic palaeolandslide in the Gobi-Altay mountains, Mongolia. Quaternary Geochronology 2, 290-295.

Bar-Yosef O. 2002. The Upper Paleolithic revolution. Annual Review of Anthropology, 31, 363-393.

Bar-Yosef, O., \& Meignen, L. 1992. Insights into Levantine Middle Paleolithic cultural variability. In H. L. Dibble \& P. Mellars (Eds.), The Middle Paleolithic: Adaptation, Behavior, and Variability (pp. 163-182). University Museum Monograph 78. University Museum, University of Pennsylvania, Philadelphia. Bar-Yosef, O. and Pilbeam, D. (eds.) 2000. The Geography of Neandertals and Modern Humans in Europe and the Greater Mediterranean. Peabody Museum, Harvard University, Cambridge, Massachusetts.

Bar-Yosef, O. and Meignen, L. (eds.). 2007. Kebara Cave Mt. Carmel, Israel. The Middle and Upper Paleolithic Archaeology. Part I. Harvard University, Cambridge, American School of Prehistoric Research Bulletin 49. Peabody Museum of Archaeology and Ethnology.

Bar-Yosef Mayer, D.E., 2005. The exploitation of shells as beads in the Palaeolithic and Neolithic of the Levant. Paléorient 31/1, 176-185.

Bar-Yosef Mayer, D.E., Vandermeersch, B. and Bar-Yosef, O. 2009. Shells and ochre in Middle Paleolithic Qafzeh Cave, Israel: Indications for modern behavior. Journal of Human Evolution 56, 307-314.

Belfer-Cohen, A. and Goring-Morris, A.N. 2009. The shift from the Middle Palaeolithic to the Upper Palaeolithic: Levantine perspectives. In: M., Camps, and C. Szmidt (Eds.), The Mediterranean from 50,000 to 25,000 BP: Turning Points and New Directions (pp.89-100). Oxbow Books, Oxford. 
Belfer-Cohen, A. and Hovers, E. 2010. Modernity, enhanced working memory, and the Middle to Upper Paleolithic record in the Levant. Current Anthropology, 51 (S1), S167-S175.

Bronk Ramsey, C. 2009. Bayesian analysis of radiocarbon dates. Radiocarbon 51, 337 360.

Bronk Ramsey, C., Higham, T.F G., Bowles, A., and Hedges, R. 2004. Improvements to the pretreatment of bone at Oxford. Radiocarbon 46, 155-163.

Buylaert, J.P., Murray, A.S. and Huot, S. 2008. Optical dating of an Eemian site in Northern Russia using K-feldspar. Radiation Measurements 43, 715-720.

Buylaert, J.-P., Murray, A.S., Thomsen, K.J. and Jain, M. 2009. Testing the potential of an elevated temperature IRSL signal from K-feldspar. Radiation Measurements $44,560-565$.

Culley E.V., Popescu G. and Clark G.A. 2013. An analysis of the compositional integrity of the Levantine Mousterian facies. Quaternary International 300, 213233.

Duller, G.A.T., 1994. Luminescence dating of sediments using single aliquots: new procedures. Quaternary Geochronology (Quaternary Science Review) 13, 149156.

Eytam, Y. and Ben-Avraham, Z. 1992. Morphology and sediments of the inner shelf off northern Israel. Israel Journal of Earth Science 41, 27-44.

Frechen, M., Neber, A., Dermann, B., Tsatskin, S., Boenigk, W. and Ronen, A. 2002. Chronostratigraphy of aeolianites from the Sharon coastal plain of Israel. Quaternary International 89, 31-44.

Frechen, M., Neber, A., Tsatskin, A., Boenigk, W. and Ronen, A. 2004. Chronology of Pleistocene sedimentary cycles in the Carmel coastal plain of Israel. Quaternary International 121:1-52.

Galbraith, R.F. and Roberts, R.G. 2012. Statistical aspects of equivalent dose and error calculation and display in OSL dating: an overview and some recommendations. Quaternary Geochronology 11, 1-27.

Galili, E., Zviely, D., Rosen, B. and Mienis, H. K. 2007. Beach deposits of MIS 5e high sea stand as indicators for tectonic stability of the Carmel coastal plain, Israel. Quaternary Science Reviews 26, 2544-2557. 
Galili, E., Ronen, A., Mienis, H.K, Horwitz, L.K. (this volume). Beach deposits containing Middle Paleolithic archaeological remains from northern Israel. Quaternary International (in press).

Garrard, A.N. 1982. The environmental implications of a reanalysis of the large mammal fauna from Wadi El-Mughara caves, Palestine. In: J. L. Bintliff and W. Van Zeist (Eds.), Palaeoclimates, Palaeoenvironments and Human Communities in the Eastern Mediterranean Region in Later Prehistory. Oxford, BAR International Series 133, pp. 165-187.

Garrod, D.A.E. and Bate D.M.A. 1937. The Stone Age of Mount Carmel: Excavations at the Wady el-Mughara, Vol. I. Oxford: Clarendon Press.

Gignoux, M., 1913. Les formations marines Pliocénes et quaternaries de l'Italie de sud et la Sicilie. Annales de l'Universite de Lyon, 36.

Goren-Inbar N. and Belfer-Cohen A. 1998. The technological abilities of the Levantine Mousterians: cultural and mental capacities. In: T. Akazawa, K .Aoki and O. BarYosef (Eds.), Neandertals and Modern Humans in Western Asia, pp. 205-222. New York: Plenum Press.

Greenbaum, N., Ekshtian, R., Malinsky-Buller, A., Porat, N. and Hovers E. 2014. The stratigraphy and paleogeography of the Middle Paleolithic open-air site of 'Ein Qashish, northern Israel. Quaternary Science Reviews 103, 153-169.

Grün, R. 2006. Direct dating of human fossils. Yearbook of Physical Anthropology 49, $2-48$.

Grün, R. and Stringer, C.B. 2000. Tabun revisited: revised ESR chronology and new ESR and U-series analyses of dental material from Tabun C1. Journal of Human Evolution 39, 601-612.

Grün, R., Stringer, C., McDermott, F., Nathan, R., Porat, N., Robertson, S., Taylor, L., Mortimer, G., Eggins, S. and McCulloch, M. 2005. U-series and ESR analyses of bones and teeth relating to the human burials from Skhul. Journal of Human Evolution 49, 316-334.

Henry, D.O. 1992. The impact of radiocarbon dating on Near Eastern prehistory. In: R. E. Taylor, A. Long, R.S. Kra (Eds.), Radiocarbon after Four Decades. Springer Science \& Business Media, New York. Pp. 324-334.

Hershkovitz I., Marder, O., Ayalon, A., Bar-Matthews, M., Yasur, G., Boaretto, E. and 18 others, 2015. Levantine cranium from Manot Cave (Israel) foreshadows the first European modern humans. Nature 520, 216-219. 
Hovers E. 2009. The Lithic Assemblages of Qafzeh Cave. Oxford University Press, Oxford.

569

Huntley, D.J. and Baril, M.R. 1997. The K content of the K-feldspars being measured in optical dating or in the thermoluminescence dating. Ancient TL 15, 11-13.

Huntley, D.J. and Lamothe, M. 2001. Ubiquity of anomalous fading in K-feldspars and the measurement and correction for it in optical dating. Canadian Journal of Earth Science 38,1093-1106.

Issar, A. 1968. Geology of central coastal plain of Israel. Israel Journal of Earth Science 17, 16-29.

Jain, M. 2009. Extending the dose range: probing deep traps in quartz with $3.06 \mathrm{eV}$ photons. Radiation Measurements 44, 445-452.

Jelinek A.J. 1981. The Middle Paleolithic in the southern Levant from the perspective of the Tabun Cave. In: J. Cauvin and P. Sanlaville (Eds.), Préhistoire du Levant. Centre National de la Recherche Scientifique, Paris, pp 265-280.

Jelinek, A.J. 1982. The Middle Paleolithic in the Southern Levant, with comments on the appearance of modern Homo sapiens. In: A. Ronen (Ed.), The Transition from Lower to Middle Paleolithic and the Origin of Modern Man. Oxford, BAR International Series 151, pp. 57-101.

Kadowaki, S. 2013. Issues of chronological and geographical distributions of Middle and Upper Palaeolithic cultural variability in the Levant and implications for the learning behavior of Neanderthals and Homo sapiens. In: T. Akazawa, Y. Nishiaki, and K. Aoki (Eds.), Dynamics of Learning in Neanderthals and Modern Humans Volume 1: Cultural Perspectives, Replacement of Neanderthals by Modern Humans Series, Springer Japan, pp. 59-91.

Langdon, J. H. 2016. Case study 20. The Neanderthal problem: Neighbors and relatives on Mt. Carmel. In: J.H. Langdon (Ed.), The Science of Human Evolution. Springer International Publishing. pp. 159-166.

Marín-Arroyo, A.B. 2013. Paleolithic human subsistence in Mount Carmel (Israel). A taphonomic assessment of Middle and Early Upper Paleolithic faunal remains from Tabun, Skhul and el-Wad. International Journal of Osteoarchaeology 23, 254-273.

McCown, T.D. and Keith, A. 1939. The Stone Age of Mount Carmel: The Fossil Human Remains from the Levalloiso-Mousterian. Vol. 2. Oxford: Clarendon Press. 
Meignen, L., Bar-Yosef, O., Speth, J. D., Stiner, M. C., 2006. Middle Paleolithic settlement patterns in the Levant. In: E. Hovers and S.L. Kuhn (Eds.), Transitions Before the Transition. Springer US, pp.149-169.

Mejdahl, V. and Bøtter-Jensen, L. 1994. Luminescence dating of archaeological materials using a new technique based on single aliquot measurements. Quaternary Geochronology (Quaternary Science Reviews) 13, 551-554.

Mercier, N., Valladas, H., Falguères, C., Shao, Q., Gopher, A., Barkai, R., Bahain, J-J., Vialettes, L., Joron, J-L. and Reyss, J-L. 2013. New datings of Amudian layers at Qesem Cave (Israel): Results of TL applied to burnt flints and ESR/U-series to teeth. Journal of Archaeological Science 40, 3011-3020.

Murray, A.S., Olley, J.M. and Caitcheon, G.C. 1995. Measurement of equivalent doses in quartz from contemporary water-lain sediments using optically stimulated Luminescence. Quaternary Geochronology 14, 365-371.

Murray, A.S. and Wintle, A.G. 2000. Luminescence dating of quartz using an improved single aliquot regenerative-dose protocol. Radiation Measurements 32, 57-73.

Nadel, D., Shtober, N., Frumkin, A. and Yaroshevich, A. 2012. New prehistoric cave sites in lower Nahal Oren, Mt. Carmel, Israel. Journal of the Israel Prehistoric Society $42,75-114$.

Nambi, K.S.V. and Aitken, M.J. 1986. Annual dose conversion factors for TL and ESR dating. Archaeometry 28, 202-205.

Neber, A. 2002. Sedimentological properties of Quaternary Deposits on the Central coastal plain. Unpublished Ph.D. dissertation. Dept. of Archaeology, University of Haifa.

Olami, Y. 1984. Prehistoric Carmel. Jerusalem: Israel Exploration Society and the M. Stekelis Museum in Haifa.

Orni, E. and Efrat, E.1971. Geography of Israel. Jerusalem: Israel Universities Press.

Porat, N., Wintle, A.G. and Ritte, M. 2004. Mode and timing of kurkar and hamra formation, central coastal plain, Israel. Israel Journal of Earth Sciences 53, 13-25.

Prescott, J.R. and Hutton, J.T. 1994. Cosmic ray contribution to dose rates for luminescence and ESR dating: Large depths and long-term time variations. Radiation Measurements 23, 497-500.

R Luminescence Developer Team, 2015. Luminescence: Comprehensive Luminescence Dating Data Analysis. R package version 0.4.5. URL: http://CRAN.Rproject.org/package=Luminescence. 
Rak, Y. 1998. Does any Mousterian cave present evidence of two hominid species? In: T. Akazawa, K. Aoki. and O. Bar-Yosef (Eds.), Neanderthals and Modern Humans in Western Asia. Plenum, New York, pp. 353-366.

Rebollo, N. R., Weiner, S., Brock, F., Meignen, L., Goldberg, P., Belfer-Cohen, A., Bar-Yosef, O. and Boaretto, E.2011 New radiocarbon dating of the transition from the Middle to the Upper Paleolithic in Kebara Cave, Israel. Journal of Archaeological Science 38:2424-2433.

Rendell, H., Yair, A. and Tsoar, H. 1993. Thermoluminescence dating of period of sand movement and linear dune formation in the northern Negev, Israel. In: K. Pye (Ed.), The Dynamics and Environmental Context of Aeolian Sedimentary Systems, vol. 72. Geological Society Special Publication, pp. 69-74.

Roberts, R.G., Jacobs, Z., Li, B., Jankowski, N.R., Cunningham, A.C. and Rosenfeld, A.B. 2015. Optical dating in archaeology: thirty years in retrospect and grand challenges for the future. Journal of Archaeological Science 56, 41-60.

Ronen, A., 1977. Mousterian sites in red loam in the Carmel coastal plain. Eretz Israel 13 (Stekelis volume). Israel Exploration Society, Jerusalem. Pp. 183-190.

Ronen, A. 1984. Sefunim Prehistoric Site, Mount Carmel, Israel. Oxford: BAR International Series 230.

Ronen, A., Tsatskin, A. and Laukhin, S.A., 1999. The genesis and age of Mousterian paleosols in the Carmel coastal plain, Israel. In: W. Davies, and R. Charles, (Eds.), Studies in Honour of D.A.E. Garrod. Oxbow Books, Oxford. pp. 135-151.

Ronen, A., Neber, A., Mienis, H., Horwitz, L.K., Frumkin, A., Boenigk, W. and Galili, E. 2008. A Mousterian occupation on an OIS 5e shore near the Mount Carmel Caves, Israel. In: Z. Sulgostowska and A.J. Tomaszewski (Eds.), Man, Millennia, Environment. Studies in Honour of Romuald Schild. Warsaw: Institute of Archaeology and Ethnology, Polish Academy of Sciences. pp 197-205.

Ronen, A. and Chernikov, I. 2010. The Mousterian of the red loam on the Carmel coast (Israel). In: J.M. Burdukiewicz, and A. Wisniewski (Eds.), Middle Palaeolithic Human Activity and Palaeoecology: New Discoveries and Ideas. Wroclaw University Press, Wroclaw, Pp. 425-446.

Shea, J. J. 2008. Transitions or turnovers? Climatically-forced extinctions of Homo sapiens and Neanderthals in the East Mediterranean Levant. Quaternary Science Reviews 27 (23-24): 2253-2270. 
Shea, J.J., 2010. Neanderthals and early Homo sapiens in the Levant. In: E.A.A. Garcea (Ed.), South-Eastern Mediterranean Peoples between 130,000 and 10,000 years Ago. Oxford, Oxbow, pp. 126-143.

Shea, J.J., 2013. Stone Tools in the Paleolithic and Neolithic Near East: A Guide. Cambridge University Press.

Sivan, D. and Porat, N. 2004. Evidence from luminescence for Late Pleistocene formation of calcareous aeolianite (kurkar) and paleosol (hamra) in the Carmel Coast, Israel. Palaeogeography, Palaeoecology, Palaeoclimatology 211, 95-106. Smedley, R.K., Duller, G.A.T., Pearce, N.J.G., Roberts, H.M., 2012. Determining the K content of single-grains of feldspar for luminescence dating. Radiation Measurements 47, 790-796.

Speth, J.D. 2012. Middle Palaeolithic subsistence in the Near East: Zooarchaeological perspectives - past, present and future. Before Farming 2: 1-45.

Thiel, C., Buylaert, J-P, Murray, A., Terhorst, B., Hofer, I., Tsukamoto, S. and Frechen, M. 2011. Luminescence dating of the Stratzing loess profile (Austria) - testing the potential of an elevated temperature post-IR IRSL protocol. Quaternary International 234, 23-31.

Tsatskin, A. and Ronen, A. 1999. Micromorphology of a Mousterian paleosol in aeolianites at the site Habonim, Israel. Catena 34, 365-384.

Valladas, H., Mercier, N., Hershkovitz, I., Zaidner, Y., Tsatskin, A., Yeshurun, R., Vialettes, L., Joron J-L., Reyss, J-L. and Weinstein-Evron, M. 2013. Dating the Lower to Middle Paleolithic transition in the Levant: A view from Misliya Cave, Mount Carmel, Israel. Journal of Human Evolution 65, 585-593

Weinstein-Evron, M., Bar-Oz, G., Zaidner, Y., Tsatskin, A., Druck, D., Porat, N. and Hershkovitz, I. 2003. Introducing Misilya Cave, Mount Carmel, Israel: A new continuous Lower/Middle Paleolithic sequence in the Levant. Eurasian Prehistory $1,31-55$.

Weinstein-Evron, M. 2015. The case of Mount Carmel: The Levant and human evolution, future research in the framework of World Heritage. In: N. Sanz (Ed.), Human Origin Sites and the World Heritage Convention in Eurasia Vol. 1. HEADS 4. Paris: UNESCO. Pp. 72-92. (http://creativecommons.org/licenses/by$\underline{\mathrm{sa} / 3.0 / \mathrm{igo} /)}$.

Weinstein, J.M. 1984. Radiocarbon dating in the southern Levant. Radiocarbon 26, 297-366. 
701 Wintle, A.G. 2008. Luminescence dating: where it has been and where it is going. Boreas 37, 471-482.

703 Yeshurun, R., Bar-Oz, G., and Weinstein-Evron, M. 2007. Modern hunting behavior in 704 the early Middle Paleolithic: Faunal remains from Misliya Cave, Mount Carmel, Israel. Journal of Human Evolution 53, 656-677.

706 Zaidner, Y., Frumkin, A., Friesem, D., Tsatskin, A., Shahack-Gross, R., 2016.

707 Landscapes, depositional environments and human occupation at Middle

708 Paleolithic open-air sites in the southern Levant, with new insights from Nesher Ramla, Israel. Quaternary Science Reviews 138, 76-86. 
Figure 1: Location map showing the Atlit Railway Bridge site (open circle marked with A) and the Sefunim (F), Tabun (T), Skhul (S), Misliya (M) and Kebara (K) caves nearby (modified from Frechen et al., 2002).

Figure 2: A log of the outcrop of aeolianites at the crossing of Highway 2 and the Atlit Railway Bridge. Three caves (marked with circled numbers 4, 9 and 10) are filled with beachrock and aeolianites that contain hearths, artifacts and faunal remains (section modified from Neber, 2002). Cave 9 (Cave III on Fig. 3 and in text) and Cave 10 (Cave II on Fig. 3 and in text) were sampled for this study. The sediments above and below the southern-most cave were previously dated by Frechen et al. (2004) using IRSL and the multiple aliquot added dose protocol (ages in ka marked within white rectangles).

Figure 3: The caves at Atlit Railway Bridge site with sampling locations. a. Cave III, now full of collapsed debris. Samples were collected from the underlying cave infilling sediments. b. Close-up of samples in Cave III. Yellow arrow shows the same rock in the two images. c. Cave II showing the different sedimentary units, the location of artifacts, fauna and OSL sample (modified from Ronen et al., 2008).

Figure 4: Faunal remains from Cave II: A. (clockwise from left: Tortoise (Testudo graeca) left hypoplastron, Fallow deer (Dama mesopotamica) left scapula neck; fragment of medium-mammal tibia shaft). B. Mountain gazelle (Gazella gazella) left proximal tibia. C. Gazelle right tibia distal epiphysis. D. Glycymeris nummaria marine shells showing holes in umbos' which may be man-made.

Figure 5: Atlit Railway Bridge lithics from Cave II (clockwise): A. Simple straight side scraper; B. Levallois flake - the piece has white patina except for the facets marked with a 'b' which are unpatinated brown flint; C. Backed knife; D. Levallois 'debordant' flake; E. Photograph of Levallois flake embedded in the kurkar. 
744 Figure 7: Luminescence signals (top), dose response curves (center) and probability

745 density function (bottom) for each of the measured minerals and signals: Left - OSL on

746 quartz; middle - pIRIR 290 on potassium feldspars; right - VSL (violet stimulated

747 luminescence) on quartz.

748

749 Figure 8: A summary of all the ages obtained using the different luminescence signals

750 and protocols for the Atlit Railway Bridge samples. The average age for each sample is 751 shown by a large, full orange circle.

\section{Table captions:}

755 Table 1: Fauna identified from the Atlit Railway Bridge site.

756

757 Table 2: Luminescence dating field and laboratory data, dose rates and ages.

758

759 Table 3: Luminescence dating measurement protocols. 


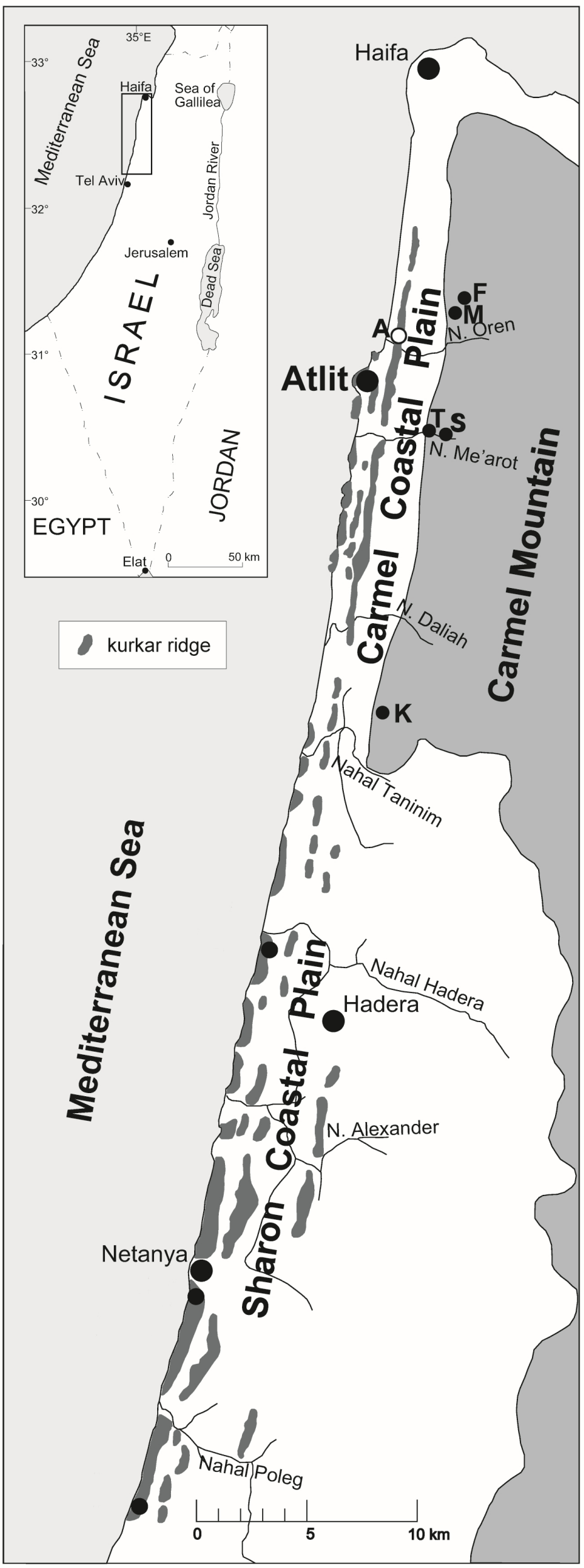




\section{M amsl $\mathbf{N}$}
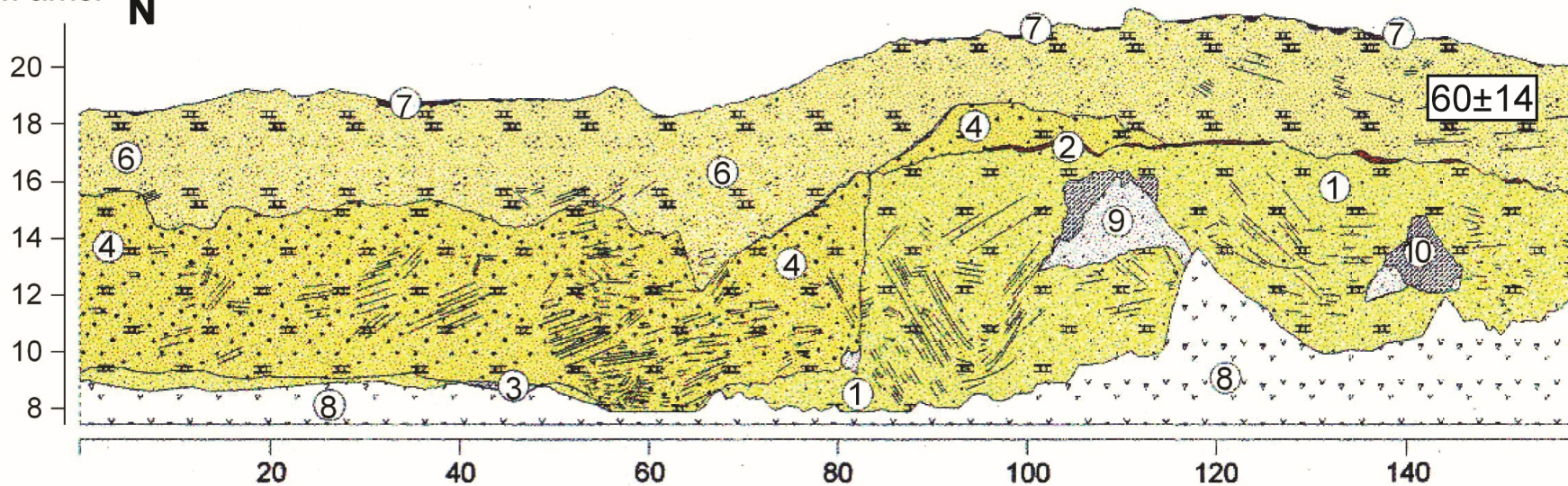

(5) middle loam

6. upper aeolianite

(7) upper loam

(8) modern debris
(1). Iower aeolianite

(2) lower loam

(3) beachrock

(4.) middle aeolianite
80
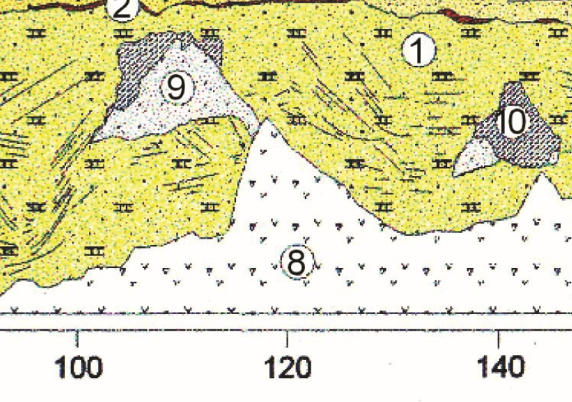

$\left.x^{x}-\frac{m}{-2}\right)^{=}$

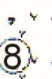

8

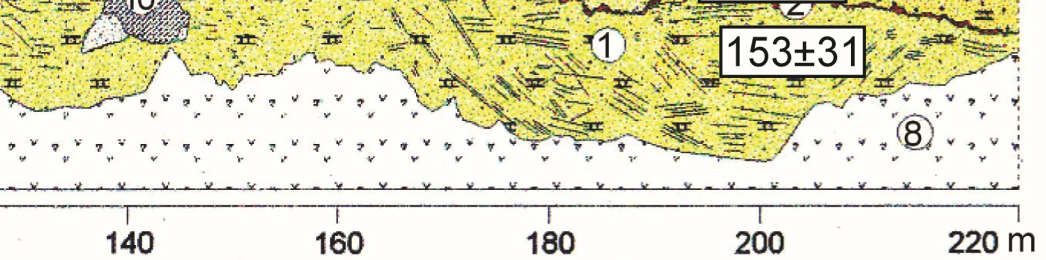

(9) cave II

(10) cave III

Ky luminescence age estimate
(7) $612 \pm 2$

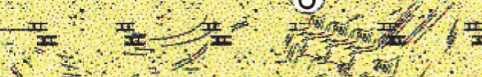

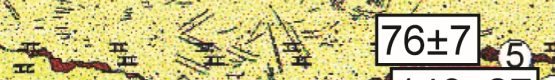
$143 \pm 27$

$143 \pm 27$

$220 \mathrm{~m}$ 

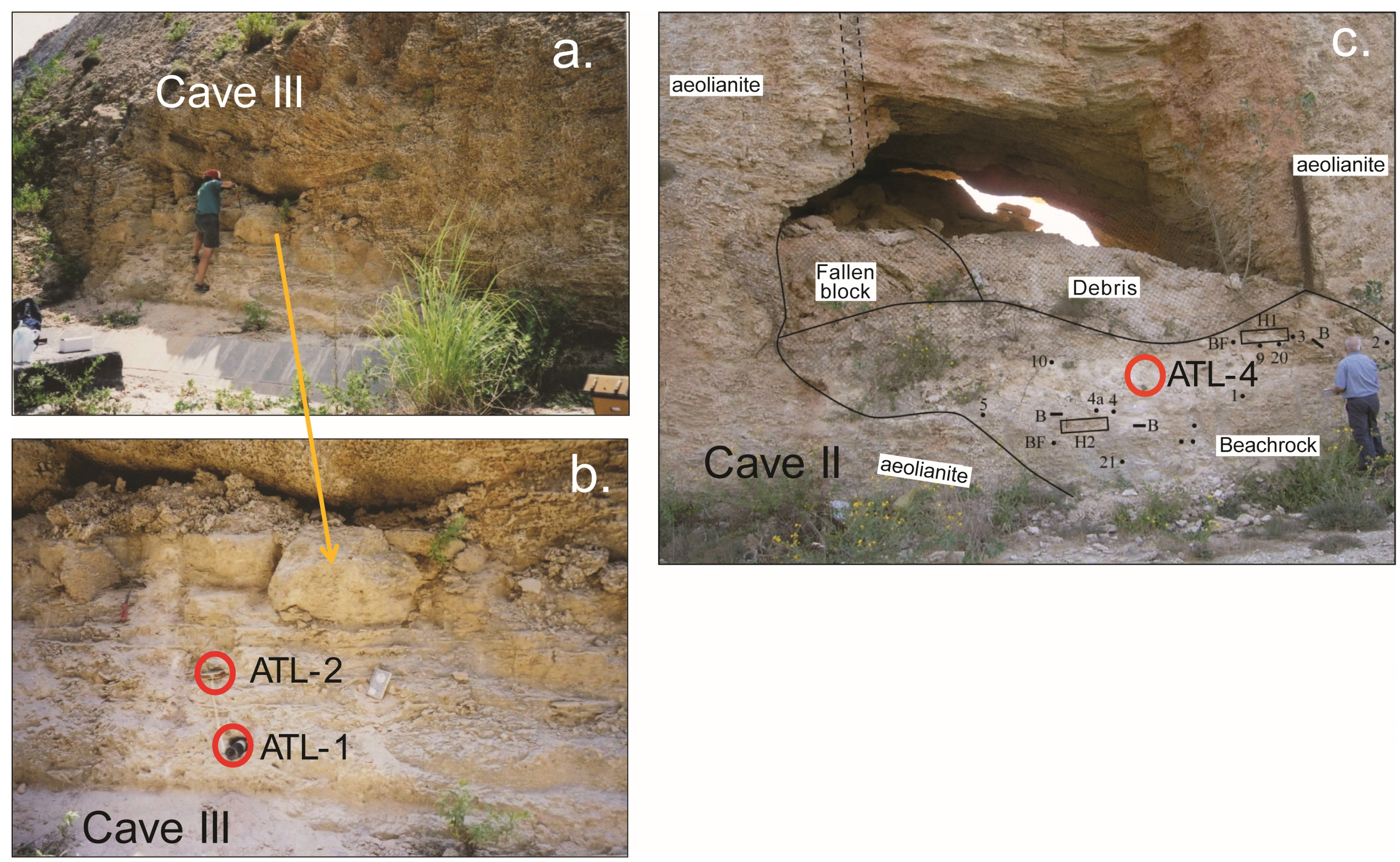


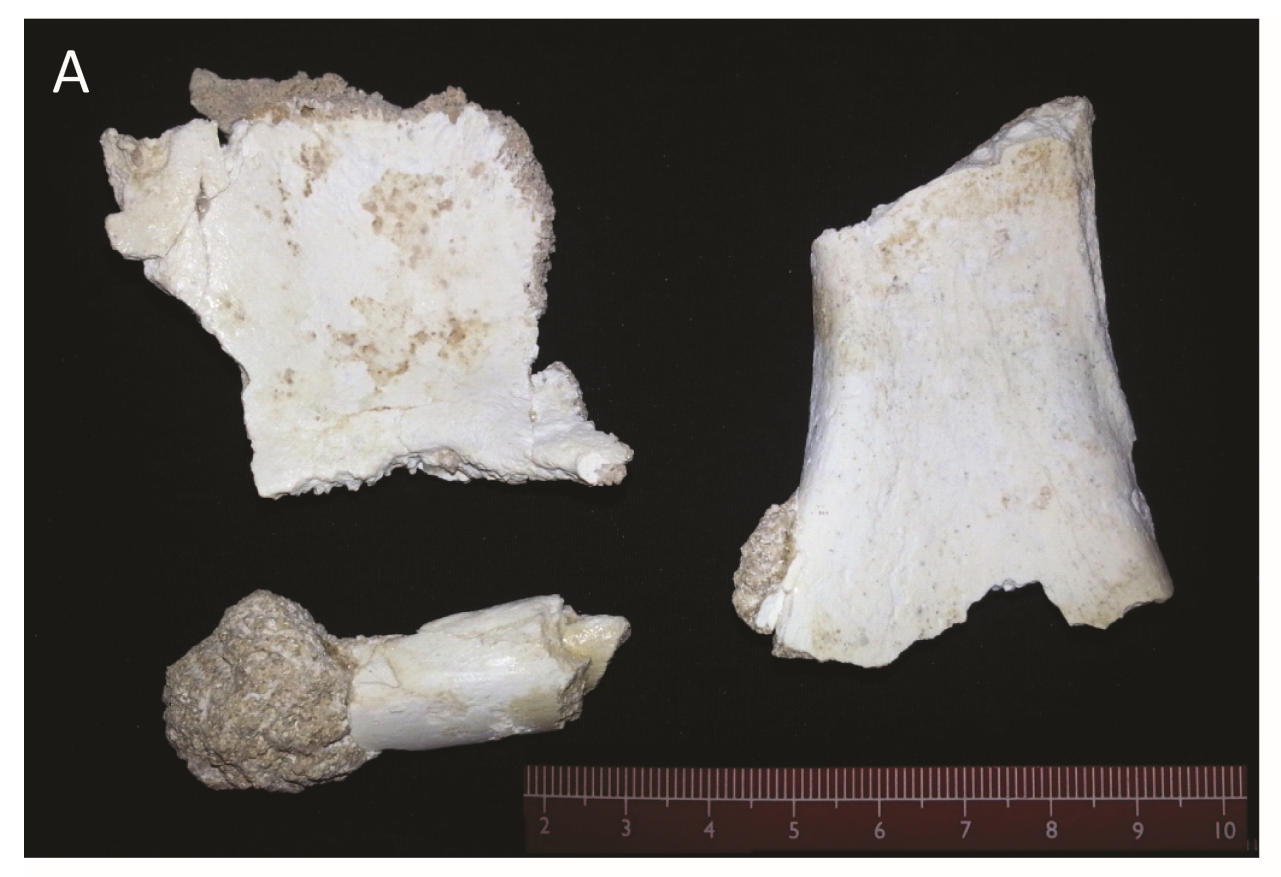

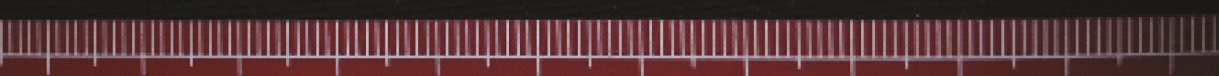

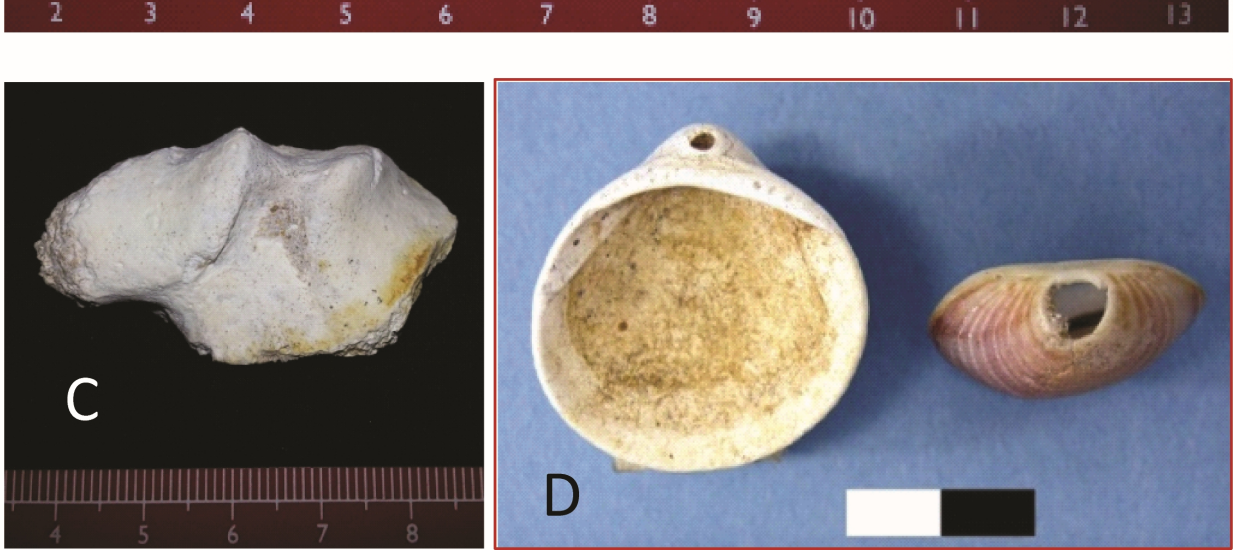




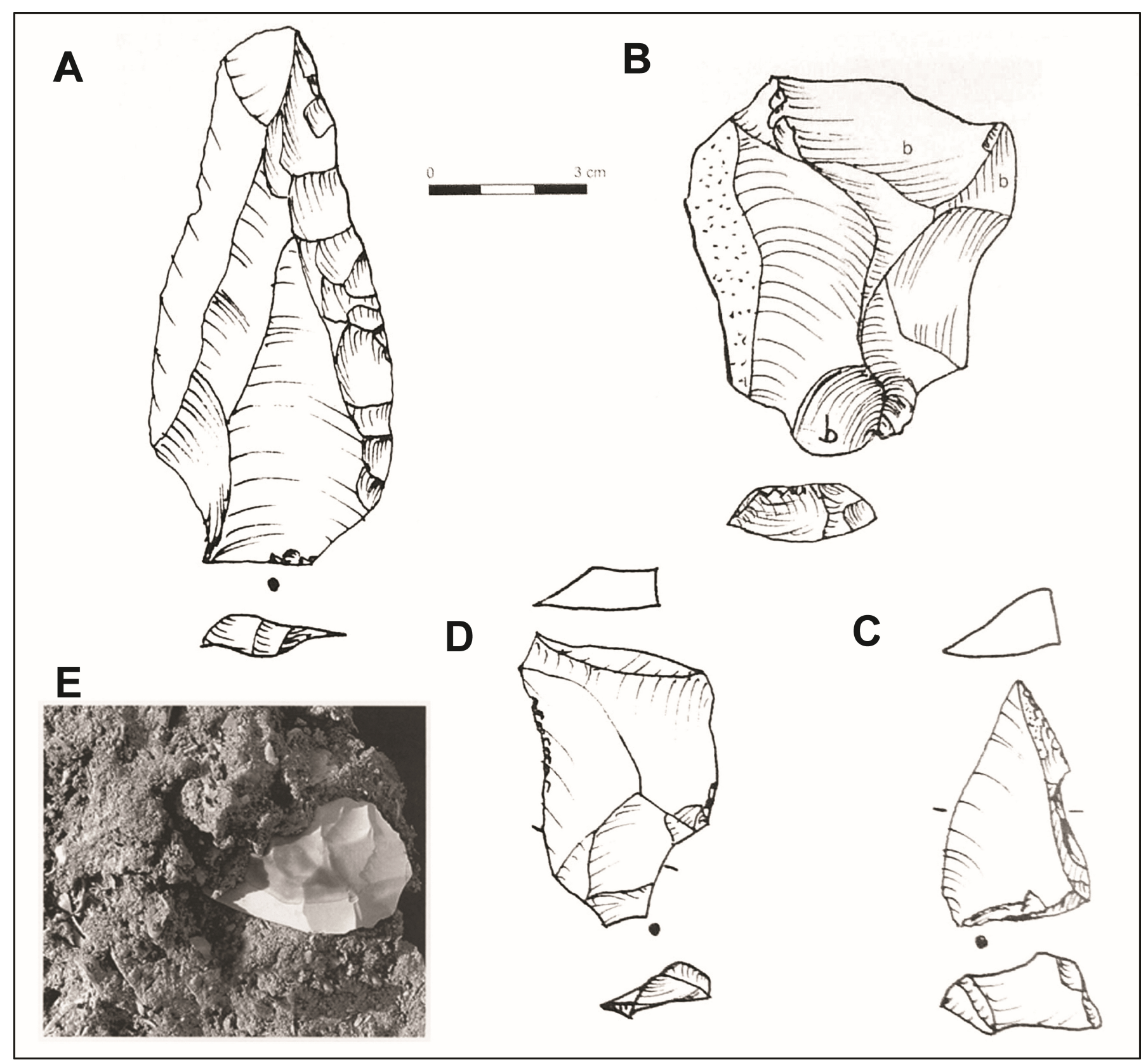




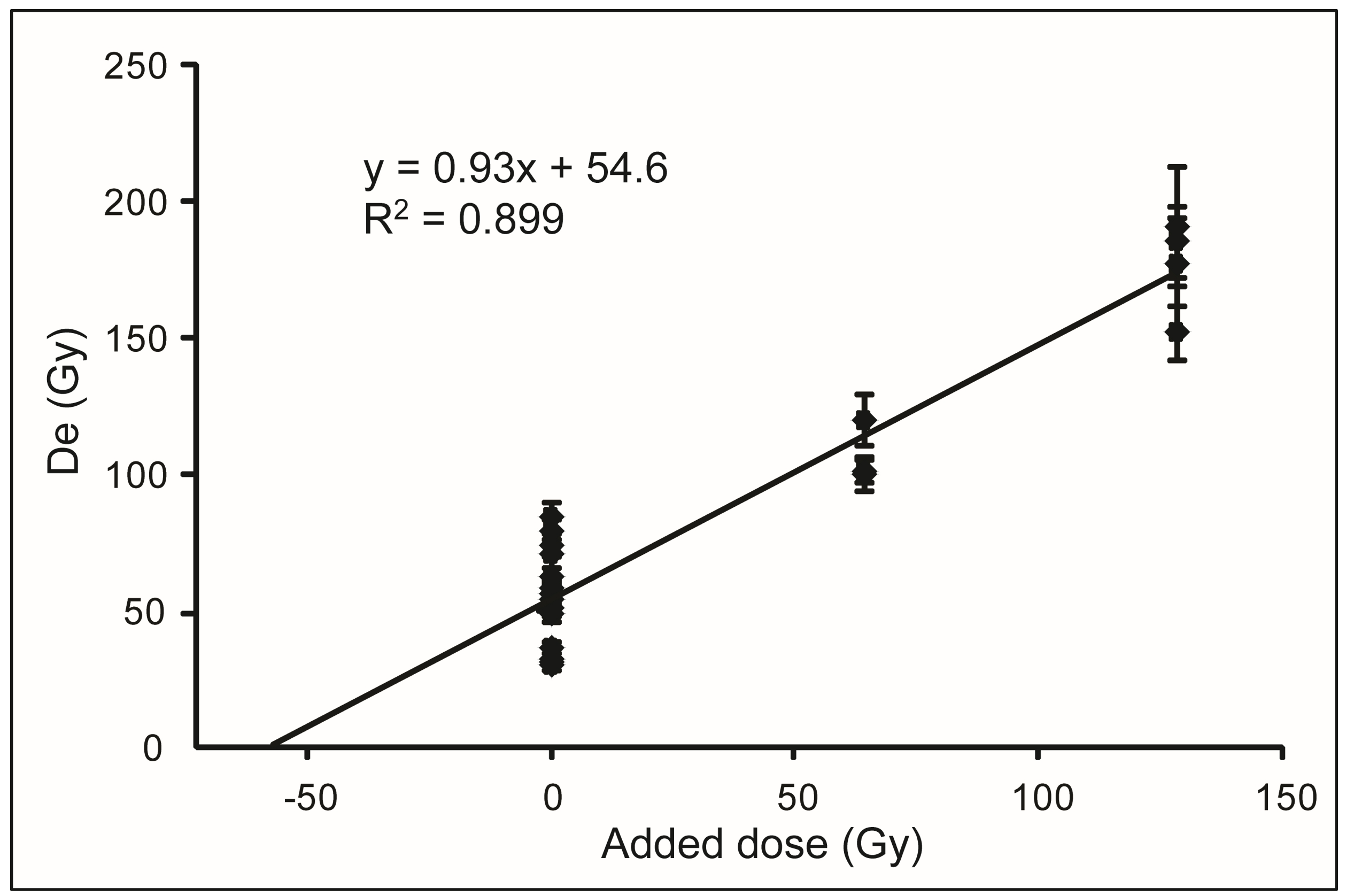



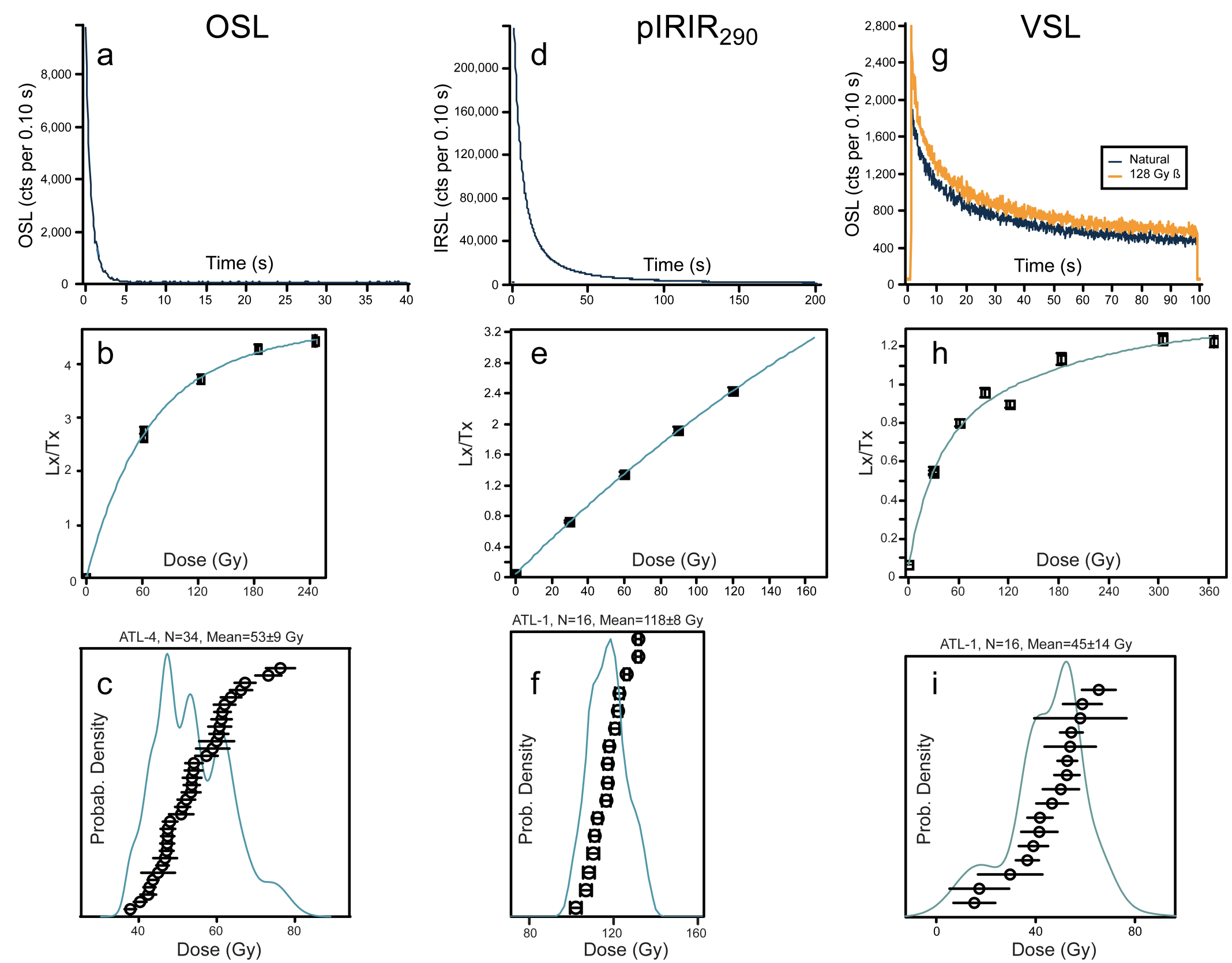


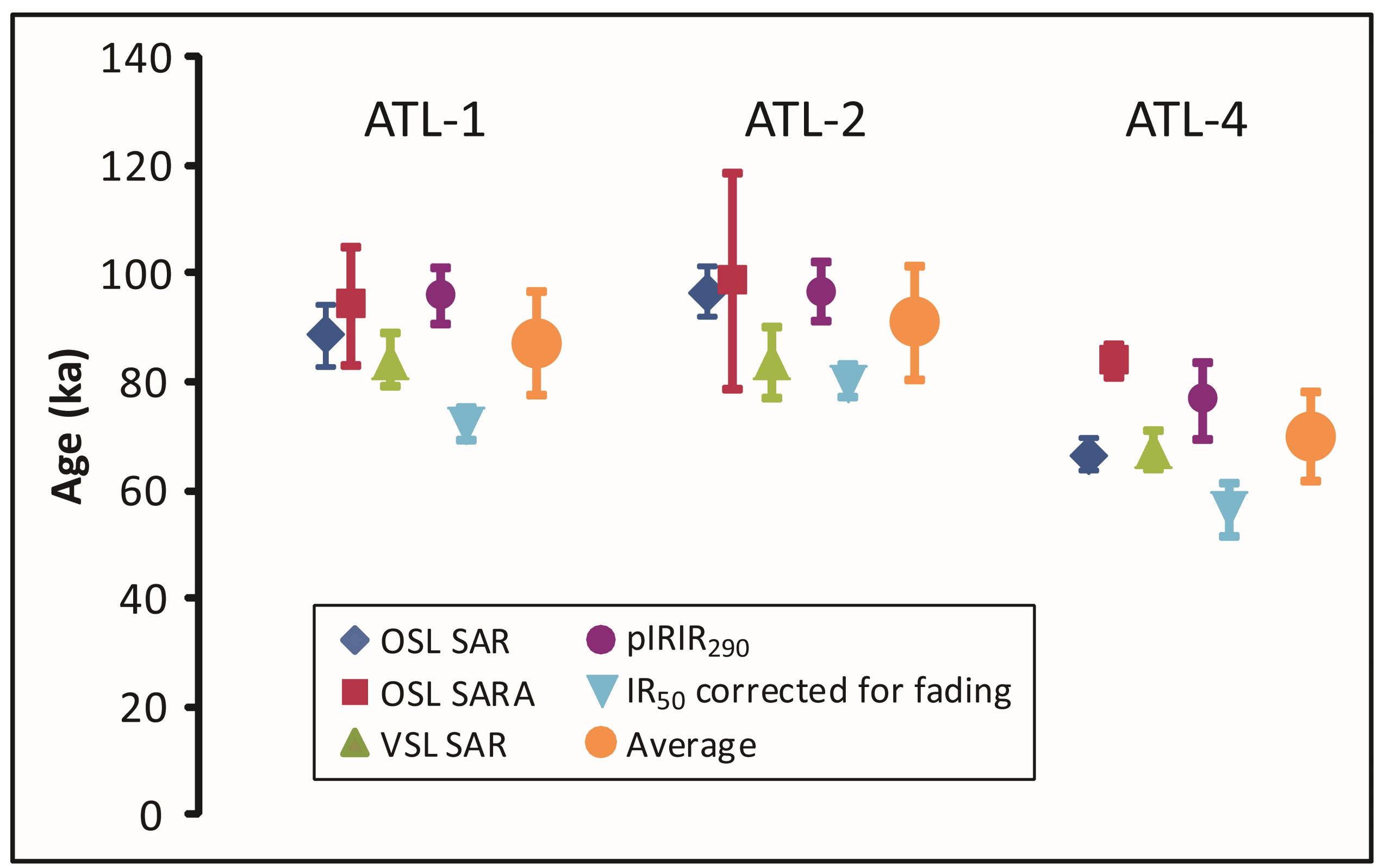


Table 1: Fauna identified from the Atlit Railway Bridge site.

\begin{tabular}{|c|c|c|}
\hline Species & Cave II & Cave III \\
\hline \multicolumn{3}{|l|}{ Artiodactyla } \\
\hline $\begin{array}{l}\text { Bovidae cf. Aurochs } \\
\text { (cf. Bos primigenius) }\end{array}$ & & $\begin{array}{l}1 \text { molar } \\
1 \text { hyoid frag. }\end{array}$ \\
\hline $\begin{array}{l}\text { Fallow deer } \\
\text { (Dama mesopotamica) }\end{array}$ & & 1 L scapula neck \\
\hline $\begin{array}{l}\text { Gazelle cf. Mountain gazelle } \\
\text { (cf. Gazella gazella) }\end{array}$ & $\begin{array}{l}1 \text { metapodial shaft frag. } \\
1 \text { metapodial prox. frag. }\end{array}$ & $\begin{array}{l}1 \mathrm{R} \text { tibia prox. epiphysis } \\
1 \mathrm{~L} \text { tibia shaft \& dist. epiphysis }\end{array}$ \\
\hline \multicolumn{3}{|l|}{ Mammalia } \\
\hline Large mammal & $\begin{array}{l}1 \mathrm{R} \text { humerus shaft }- \text { Bos/Cervus size } \\
\text { undet. long bone shaft frag. } \\
7 \text { undet. long bone shaft frag. }\end{array}$ & \\
\hline Medium mammal & & $\begin{array}{l}3 \text { undet. long bone shaft } \\
\text { frags cf. Gazelle tibia }\end{array}$ \\
\hline \multicolumn{3}{|l|}{ Aves } \\
\hline $\begin{array}{l}\text { cf. partridge } \\
\text { (cf. Alectoris chukar) }\end{array}$ & $1 \mathrm{R}$ dist. tibiotarsus & \\
\hline $\begin{array}{l}\text { Ostrich } \\
\text { (Struthio camelus) }\end{array}$ & 1 eggshell frag. & \\
\hline \multicolumn{3}{|l|}{ Reptilia } \\
\hline $\begin{array}{l}\text { Spur thighed tortoise } \\
\text { (Testudo graeca) }\end{array}$ & & 1 R hypoplastron \\
\hline \multicolumn{3}{|l|}{ Mollusca } \\
\hline Glycymeris nummaria* & & 2 valves \& 3 frags. \\
\hline Acanthocardia tuberculata & & 2 frags. \\
\hline Cerastoderma glaucum & & 1 frags. \\
\hline Donax trunculus & & 2 frags. \\
\hline
\end{tabular}


*previous name for this species was Glycymeris insubrica

Key: prox=proximal; dist $=$ distal; $\mathrm{L}=\mathrm{left} ; \mathrm{R}=$ right; undet $=$ undetermined; frag. = fragment 
Table 2: Luminescence dating field and laboratory data, dose rates and ages.

\begin{tabular}{|c|c|c|c|c|c|c|c|c|c|c|c|c|c|}
\hline Lab code & $\begin{array}{c}\text { Grain } \\
\text { Size } \\
(\mu \mathrm{m})\end{array}$ & $\begin{array}{c}K \\
(\%)\end{array}$ & $\begin{array}{c}\mathrm{U} \\
(\mathrm{ppm})\end{array}$ & $\begin{array}{c}\text { Th } \\
\text { (ppm) }\end{array}$ & $\begin{array}{c}\text { Ext. } \alpha \\
(\mu \mathrm{Gy} / \mathbf{a})\end{array}$ & $\begin{array}{c}\text { Ext. } \beta \\
(\mu \mathrm{Gy} / \mathbf{a})\end{array}$ & $\begin{array}{c}\text { Ext. } \gamma \\
(\mu \mathrm{Gy} / \mathbf{a})\end{array}$ & $\begin{array}{c}\text { Dose rate } \\
(\mu G y / a)\end{array}$ & $\begin{array}{c}\text { No. } \\
\text { aliquots }\end{array}$ & $\begin{array}{l}\text { OD } \\
(\%)\end{array}$ & $\begin{array}{c}\text { De } \\
\text { (Gy) }\end{array}$ & $\begin{array}{c}\text { Fading } \\
\text { (\%/decade) }\end{array}$ & $\begin{array}{l}\text { Age } \\
\text { (Ka) }\end{array}$ \\
\hline $\begin{array}{l}\text { ATL-1 QZ OSL } \\
\text { ATL-1 QZ SARA } \\
\text { ATL-1 QZ VSL } \\
\text { ATL-1 KF IR } 50 \\
\text { ATL-1 KF IR } 290 \\
\text { Average: }\end{array}$ & $\begin{array}{l}88-125 \\
125-210\end{array}$ & 0.07 & 1.73 & 0.82 & 5 & 265 & 226 & $580 \pm 21$ & $\begin{array}{l}30 \\
24 \\
16 \\
16 \\
16\end{array}$ & $\begin{array}{c}28 \\
12 \\
9 \\
6\end{array}$ & $\begin{array}{l}51.5 \pm 2.7 \\
54.6 \pm 6.6 \\
48.8 \pm 2.4 \\
68.8 \pm 1.6 \\
118 \pm 2.1\end{array}$ & $2.6 \pm 0.4$ & $\begin{array}{r}89 \pm 6 \\
94 \pm 11 \\
84 \pm 5 \\
73 \pm 6 * \\
96 \pm 5 \\
87 \pm 9\end{array}$ \\
\hline $\begin{array}{l}\text { ATL-2 QZ OSL } \\
\text { ATL-2 QZ SARA } \\
\text { ATL-2 QZ VSL } \\
\text { ATL-2 KF IR } 50 \\
\text { ATL-2 KF IR } 290 \\
\text { Average: }\end{array}$ & $\begin{array}{r}\text { 88-125 } \\
125-210\end{array}$ & 0.07 & 1.46 & 0.58 & 83 & $\begin{array}{l}228 \\
229\end{array}$ & 188 & $\begin{array}{c}505 \pm 19 \\
1138 \pm 144\end{array}$ & $\begin{array}{l}31 \\
24 \\
21 \\
12 \\
12\end{array}$ & $\begin{array}{c}18 \\
30 \\
7 \\
7\end{array}$ & $\begin{array}{l}48.8 \pm 1.7 \\
49.7 \pm 9.9 \\
42.3 \pm 2.9 \\
66.4 \pm 1.5 \\
110 \pm 2.3\end{array}$ & $3.0 \pm 0.3$ & $\begin{array}{r}97 \pm 5 \\
99 \pm 20 \\
84 \pm 7 \\
80 \pm 6 * \\
97 \pm 5 \\
91 \pm 9\end{array}$ \\
\hline $\begin{array}{l}\text { ATL-4 QZ OSL } \\
\text { ATL-4 QZ SARA } \\
\text { ATL-4 QZ VSL } \\
\text { ATL-4 KF IR } 50 \\
\text { ATL-4 KF IR } 290\end{array}$ & 125-210 & 0.08 & 2.77 & 0.50 & 149 & 386 & 320 & $\begin{array}{r}798 \pm 25 \\
1495 \pm 151\end{array}$ & $\begin{array}{l}34 \\
24 \\
30 \\
12 \\
12\end{array}$ & $\begin{array}{c}21 \\
3 \\
8\end{array}$ & $\begin{array}{l}53.2 \pm 1.6 \\
66.9 \pm 0.8 \\
53.8 \pm 2.2 \\
62.8 \pm 0.7 \\
115 \pm 2.7\end{array}$ & $3.1 \pm 0.2$ & $\begin{array}{r}67 \pm 3 \\
84 \pm 3 \\
67 \pm 4 \\
58 \pm 4 * \\
77 \pm 4\end{array}$ \\
\hline
\end{tabular}


Notes: Internal beta dose rate for alkali feldspars was calculated using K-contents of $12 \pm 0.5 \%$ and an estimated a-value of $0.15 \pm 0.05$, giving a value of $553 \pm 50 \mu \mathrm{Gy} / \mathrm{a}$ for the specific grain size (not in Table). Cosmic dose rate was evaluated at $85 \mu \mathrm{Gy} / \mathrm{a}$ from estimated burial depth of $8 \pm 1 \mathrm{~m}$ (not in Table). Moisture contents were estimated at $10 \pm 3 \%$. Aliquots used - the number of aliquots used for the average De out of those measured. OD- Overdispersion, a measure of scatter within the sample beyond that expected from analytical noise. De averages and errors were calculated using the central age model (Galbraith and Roberts 2012). * $\mathrm{IR}_{50}$ ages were corrected for fading using the measured rates. 
Table 3: Luminescence dating measurement protocols.

\begin{tabular}{|c|c|c|c|}
\hline & a. OSL & b. VSL & c. IRSL \\
\hline 1 & Give a regen dose $($ for $N$ dose $=0)$ & Give a regen dose (for N dose $=0)$ & Give a regen dose $($ for $N$ dose $=0)$ \\
\hline 2 & Preheat for $10 \mathrm{~s} @ 260^{\circ} \mathrm{C}$ & Preheat for $100 \mathrm{~s} @ 300^{\circ} \mathrm{C}$ & Preheat for $60 \mathrm{~s} @ 320^{\circ} \mathrm{C}$ \\
\hline 3 & Measure OSL with LED for $40 \mathrm{~s} @ 125^{\circ} \mathrm{C}(\mathrm{Ln})$ & Measure OSL with LED for $100 \mathrm{~s} @ 125^{\circ} \mathrm{C}$ & Measure IRSL for $200 \mathrm{~s} @ 50^{\circ} \mathrm{C}$ \\
\hline 4 & Give a test dose of $\sim 10 \mathrm{~Gy}$ & Measure VSL for 100 s @ RT (Ln) & Measure IRSL for $200 \mathrm{~s} @ 290^{\circ} \mathrm{C}$ (Ln) \\
\hline 5 & Preheat for $10 \mathrm{~s} @ 220^{\circ} \mathrm{C}$ & Give a test dose of $\sim 50 \mathrm{~Gy}$ & Give a test dose of $32 \mathrm{~Gy}$ \\
\hline 6 & Measure OSL with LED for $40 \mathrm{~s} @ 125^{\circ} \mathrm{C}(\mathrm{Tn})$ & Preheat for $100 \mathrm{~s} @ 290^{\circ} \mathrm{C}$ & Preheat for $60 \mathrm{~s} @ 320^{\circ} \mathrm{C}$ \\
\hline 7 & Deplete remaining OSL for $100 \mathrm{~s} @ 280^{\circ} \mathrm{C}$ & Measure OSL with LED for $100 \mathrm{~s} @ 125^{\circ} \mathrm{C}$ & Measure IRSL for $200 \mathrm{~s} @ 50^{\circ} \mathrm{C}$ \\
\hline 8 & Return to Step 1 & Measure VSL for 100 s @ RT (Tn) & Measure IRSL for $200 \mathrm{~s} @ 290^{\circ} \mathrm{C}(\mathrm{Tn})$ \\
\hline 9 & & Deplete remaining VSL for $200 \mathrm{~s} @ 280^{\circ} \mathrm{C}$ & Deplete remaining IRSL for $200 \mathrm{~s} @ 325^{\circ} \mathrm{C}$ \\
\hline 10 & & Return to Step 1 & Return to Step 1 \\
\hline
\end{tabular}

Notes: OSL (optically stimulated luminescence) protocol modified from Wintle and Murray (2006); VSL (violet stimulated luminescence) modified from Jain et al. (2009); IRSL (infrared stimulated luminescence) protocol from Thiel et al. (2011), which includes both $\operatorname{IR}_{50}$ and pIRIR 290 (p stands for post). The signals used for constructing a dose response curve and calculating the De are shaded. 